Вісник Дніпропетровського університету. Серія: Геологія, географія Vìsnik Dnìpropetrovs'kogo unìversitetu. Serîa: Geologîa, geographìâ

Dnipropetrovsk University bulletin. Seria:Geology, geography

Dnipropetr. Univ. Bull. Ser.: Geol., geogr. 2015. 23(1), 50-55.

doi: $10.15421 / 111506$

ISSN 2313-2159 print

ISSN 2409-9864 online

http://geology-dnu.dp.ua

УДК $622.278+662.73$

\title{
Оцінка можливості використання підземних вод зони термічного впливу промислових підприсмств
}

\section{С. В. Жолудсв}

Дніпропетровський національний університет імені Олеся Гончара.,

Проаналізовано гідродинамічні особливості нагрітих підземних вод. Доведено, що води термічної зони високотемпературних промислових об'єктів мають достатньо високі теплові характеристики i їх можна застосовувати у відомих схемах теплових помп та породних акумуляторів із мінімальними модифікаціями.

Ключові слова: теплова енергія, геотехнічна система, підземні води, теплова помпа, породний акумулятор.

The possibility estimation of the thermal underwater affected by industrial enterprises for using

\section{S. V. Zholudev}

Oles Honchar Dnipropetrovsk National University

The analysis of hydrodynamic features of the heated underwater is in process conducted and it is well-proven that water of thermal area of high temperature industrial objects has high enough thermal parameters and can be used in the well-known heat-pumping and soil heat accumulators technologies with minimum modifications.

Key-words: thermal energy, geotechnical system, underground water, heat-pump, soil heat accumulator.

Вступ. Як рідкі рухомі теплоносії можна використовувати розплави металів, солі та інші середовища [9]. За наявності термічних підземних вод їх також можна використовувати як кондиційні низькопотенціальні теплоносії, але застосування такої теплової енергії пов'язане з деякими труднощами, однією з яких є відносно

Дніпропетровський національний університет імені Олеся Гончара, пр. Гагаріна, 72 , м. Дніпропетровськ, 49010, Україна.

Oles Honchar Dnipropetrovsk National University, pr. Gagarina, 72, Dnipropetrovsk, 49010, Ukraine.

Tel.: +38-050-520-08-46. E-mail: ggf2009@ukr.net 
малий тепловий потік. Тому для його вилучення необхідно розробити методи $\mathrm{i}$ засоби концентрації та передачі. Наприклад, за допомогою системи природних або штучних каналів і технічних засобів, що забезпечують виведення теплоносія із надр на земну поверхню. Водоносний горизонт по суті - породний, тобто штучний теплообмінник, що являє собою ділянки масиву гірських порід зі штучно підвищеною температурою (доменна піч, конвертер тощо) [3]. Таким чином, підземні води в області термічного впливу доменної печі можна назвати рухомим теплоносієм. Нижче зображено приблизну схему подібного процесу (рис. 1).

Матеріал i методи досліджень. За наявними даними фундаменти високотемпературних об'єктів розміщуються як правило на глибинах, де підземні води знаходяться у перегрітому стані. Залежно від ступеня теплового забруднення ця глибина може сягати $10-13$ м, а в умовах гомогенного середовища - 20 м [10].

Підземні води даної термічної зони знаходяться у стані бінарної (газованої) рідини або газоподібному стані, оскільки іiі температура має показники вищі за температуру критичної точки води. Вплив водяної пари настільки значний, що поділ фаз враховують у всіх термічних і газогідродинамічних обчисленнях [8].

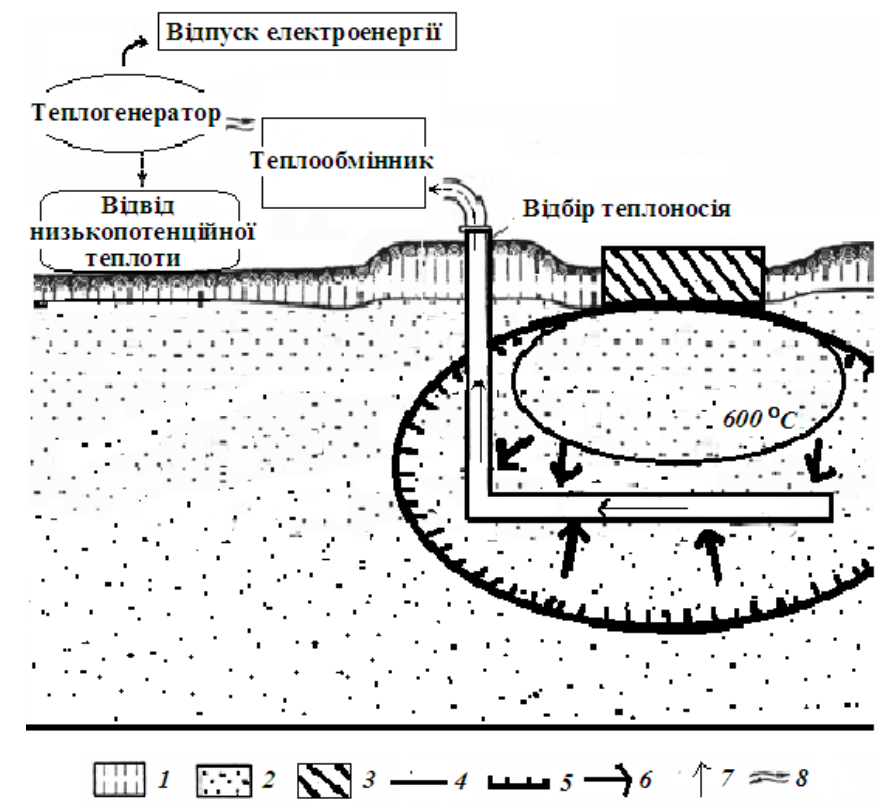

Рис. 1. Схема відбору теплоносія зони термічного впливу промислового підприємства: 1 - поверхневий шар; 2 - піски; 3 - фундамент; 4 - ізотерма $600{ }^{\circ} \mathrm{C} ; 5$ - межа зони термічної дії; 6 - напрям руху теплоносія; 7 - виведення теплоносія на поверхню; 8 - циркуляція теплоносія в наземній частині

Двофазний потік фільтрує через прогріту товщу порід і продовжує перебувати в зоні теплового впливу підприємства. Отже, на цій ділянці теплових втрат немає, навпаки, можливе додаткове нагрівання.

У горизонтальному і вертикальному водовідбірних каналах свердловини або галереї режим двофазного потоку зберігається. Для підземної води як теплоносія вона досить добре моделює перетин двофазних однокомпонентних середовищ (водяна пара - вода) за адіабатної течії. У разі підведення тепла від доменної печі ситуація буде майже така сама, тому спочатку розглянемо випадок відсутності теплового впливу $[1,2]$. 
Розрізняють шість основних режимів потоку двофазних середовищ: бульбашковий, снарядний, відшарований, дисперсно-кільцевий, емульсійний, збагачений дисперсно-кільцевий. Крім зазначених виділяють проміжні - різновиди шести основних типів [11]. Формування того чи іншого режиму потоку залежить від низки умов і фізичних характеристик: витрат фаз, орієнтації потоку в просторі, геометрії каналу, поверхневого натягу рідкої фази, щільності й в'язкості фаз.

У необігрітому каналі 3 малими витратами двофазної суміші і малим паровмістом пар розподіляється в потоці у вигляді окремих невеликих бульбашок (бульбашковий режим). $\mathrm{y}$ разі зростання швидкості потоку бульбашки концентруються в приосьовій частини труби і має місце дисперсно-кільцевий режим, за якого одна частина рідини тече уздовж стінок каналу у вигляді плівки, а інша розподілена в газовому потоці у вигляді крапель. Товщина плівки рідини нерівномірна по периметру. Межі окремих режимів визначають досить умовно.

Випадок, коли на теплоносій термічно впливає, наприклад, доменна піч, оскільки водозабірний канал (труба) одним кінцем перебуває в області теплового впливу доменної печі й по всій своїй довжині слугує своєрідним нагрівальним елементом, більш складний. На стінці каналу відбувається поверхневе кипіння, кількість пари безперервно зростає і вона рухається вздовж поверхні. Пристінний шар у даному випадку також двофазний, а бульбашки, що утворюються в ньому, руйнуються через конденсацію в недогрітих шарах рідини. Таким чином, тепло передається ядру потоку і вниз за течією недогрів зменшується.

$\mathrm{У}$ момент досягнення рідиною температури насичення настає бульбашковий режим. По всьому каналу бульбашки пари починають рухатися в потоці насиченої рідини. Далі зі збільшенням паровмісту потік двофазного середовища розділяється на два потоки: на поверхні каналу тече плівка рідини, а в приосьовій зоні рухається пара із краплями рідини (дисперсно-кільцевий режим). Але в умовах руху по трубі, яка нагрівається, він має деякі відмінності від адіабатного потоку.

За дисперсно-кільцевого режиму відбувається безперервний масообмін між плівкою рідини і рідкою фазою в ядрі потоку, тобто частина рідини з ядра потрапляє на плівку під дією турбулентних пульсацій, а з поверхні плівки падають нові краплі, які, у свою чергу, потрапляють у ядро. У разі підведення тепла ця рівновага порушується: випадає рідини менше, ніж відноситься, тобто плівка поступово тоншає. Згодом плівка руйнується і настає емульсійний режим течії, за якого плівки на поверхні немає і весь потік складається з пари, що містить краплі рідини.

За досить значну довжину каналу і перепадах температур на його кінцях можна спостерігати явище, коли температура води, яку відкачують, нижча температури стінок водозабірного каналу. При цьому структура двофазного потоку змінюється. У ядрі тече недогріта рідина, а уздовж стінок - парорідинна емульсія, тобто паровий потік із краплями рідини. Такий режим називають збагаченим дисперснокільцевим i він для нашого випадку малоймовірний, враховуючи порівняно невелику довжину шляху фільтрації.

Очевидно, що процеси, які відбуваються на цьому етапі транспортування, не знижують енергію теплоносія. Більше того, можна припустити, що вони певним чином «пристосовують» його до споживання енергогенеруючою установкою, збільшуючи паровміст. Ці висновки грунтуються на вивченні теоретичних закономірностей і мають якісний характер.

У разі підведення тепла від нагрітого доменною піччю геологічного

Dnipropetr. Univ. Bull. Ser.: Geol., geogr. 2015. 23(1) 
середовища в горизонтальному каналі спостерігаються ті ж режими, що й у вертикальному, i, крім того, за малих масових витратах можливі розшаровані режими. Припустити, що в даному випадку не буде відбуватися особливого охолодження теплоносія. Але цей варіант компонування можна розглядати окремо [10].

За хвильового режиму мають місце розглянуті режими течії потоку із розшаруванням і його модифікацією $[5,6]$. За будь-якого паровмісту потоки пари i рідини розділяються (відшарований режим). Поверхня розділу фаз у цьому випадку лише за досить малих витратах плоска. Зі зростанням швидкості на поверхні утворюються хвилі, амплітуди і довжини яких залежать від швидкостей фаз і їх фізичних властивостей. За великих швидкостей амплітуда хвилі сягає величини порядку діаметра труби, і потік має знарядний характер, тобто в потоці рідини $є$ великі вкраплення пари (знаряди), розділені рідкими перемичками. Парові об'єми зміщені до верхньої частини труби, де плівка рідини тонша. За досить великого тиску може відбуватися зміна рівня концентрації пари, достатня для переходу від бульбашкової структури до туманоподібної. У результаті утворюються два супутніх потоки - двофазний туманоподібний біля стінки і краплиннорідкий у центральній частині каналу. Аналітичне дослідження подібних двофазних течій із багатьох причин утруднено через необхідність знати точний розподіл меж фаз [7]. Але за відносно малих швидкостей руху води та невеликого тиску, які саме i пропанують застосовувати, ці явища не спостерігаються.

Отже, можна зробити висновок про потенційну можливість використання підземних вод як кондиційного теплоносія. Більше того, подібне технічне рішення дозволяє застосовувати загальновідому технологію теплової помпи 3 деякими змінами.

Теплова помпа - це компактна енергетична установка, основна відмінність якої від інших генераторів теплової енергії, наприклад електричних, газових i дизельних, полягає в тому, що в ході вироблення тепла до $80 \%$ енергії «витягується» 3 навколишнього середовища. Теплова помпа «викачує» енергію, накопичену в грунті, скельній породі, водоймах і навіть повітрі.

Зовнішній контур теплової помпи збирає теплову енергію навколишнього середовища. Грунт добре акумулює енергію, але джерелом тепла можуть бути i підземні води. Для їх використання необхідно побудувати мережу водовідбірних та скидних свердловин і виробок.

Технологія теплової помпи розрахована на відносно низькі температури, порівняно 3 тепловим полем високотемпературних промислових об'єктів. Щоб перетворити температуру фреону $3+8{ }^{\circ} \mathrm{C}$, яку він отримує із грунту, на $+75^{\circ} \mathrm{C}$, потрібно стискати його в компресорі до 26 атмосфери. Після віддавання контуром тепла необхідно застосувати дросельний пристрій для зниження тиск знову до 4 атмосфер.

Оскільки в нашому випадку теплоносій (підземні води) має температуру, значно вищу за температуру звичайного грунтового режиму без техногенного впливу, теплову помпу можна значно спростити - установити компресор набагато меншої потужності, якої б вистачило для циркуляції розчину в контурі без збільшення тиску, і прибрати дросельний пристрій; оскільки тиск не збільшувався, немає потреби його знижувати для скидання відпрацьованого теплоносія.

У разі використання грунту 3 температурою $+8{ }^{\circ} \mathrm{C}$ як джерела тепла зовнішній контур, що збирає тепло навколишнього середовища, опускають у 
свердловину на $50-100$ м (вертикальний теплообмінник) або закопують на глибину 1,2-2 м (горизонтальний теплообмінник). Якщо ж теплова помпа братиме тепло із зони теплового впливу промислового підприємства, такі глибини не потрібні. Достатньо буде розмістити контур, що збирає тепло, у межах термічної зони промислового об'єкта, розмір якого не залежить від сезонного фактора і не змінюється упродовж року.

Ще одним із варіантів можливого використання прогрітих підземних вод термічної зони промислового підприємства може бути схема так званого «породного акумулятора» (рис. 2).

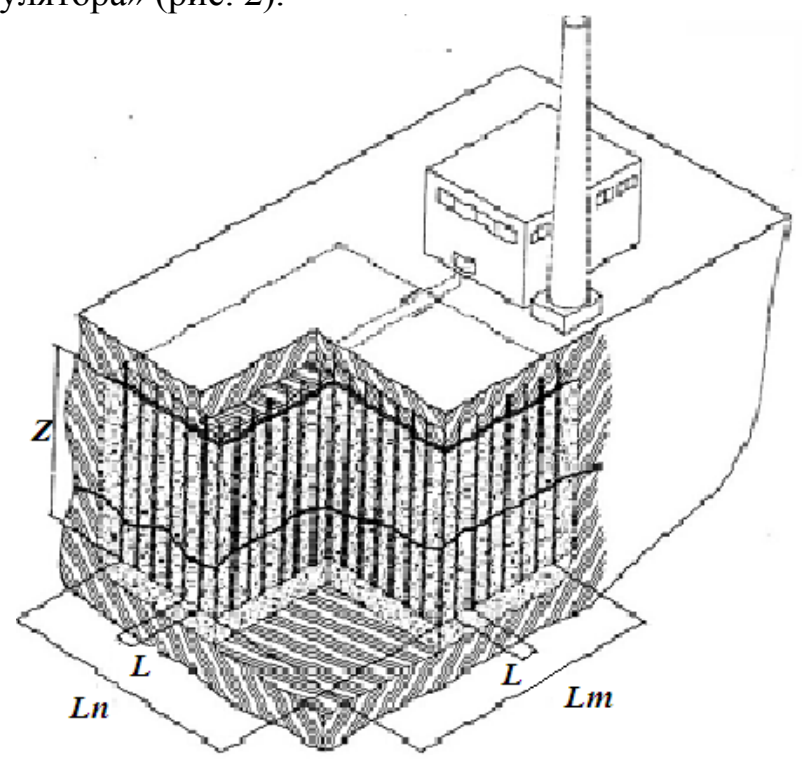

Рис. 2 Схема породного акумулятора:

$Z$ - висота (глибина) акумулятора; $L n-$ - ширина теплообмінників; $L m$ - довжина теплообмінників; $L-$ - крок між теплообмінниками

Застосування даної схеми передбачає будівництво мережі спеціальних

свердловин, що збирають термічно і хімічно забруднену підземну воду, яку фільтрують через систему радіаторів, у якій іï очищують та готують для подальшого використання як теплоносія. Застосування цієї технології дозволяє отримати не лише кондиційний рухомий теплоносій, але і допомагає відбирати хімічні речовини, що забруднюють геологічне середовище, насамперед підземні води. Крім економічної вигоди від отримання теплової і електроенергії також можливо додатково отримувати прибуток від очищення підземних вод за рахунок виділення із них цінних хімічних сполук (алюмінію, заліза тощо), які завжди вважали промисловими хімічними забруднювачами.

Сам процес очищення достатньо простий. Регулюючи зниження рівня підземних вод, можна контролювати непоширення забруднення. Система флокуляції та окиснення складається з чотирьох блоків: флокуляційної камери, трубчастого відстійника, пісочного фільтра, камерного відстійника. Для збільшення pH та осадження важких металів у підземній воді у флокуляційній камері додають гідроокис натрію, розчин хлору і полімер. Гідроксид натрію реагує з важкими металами з утворенням гідроксиду металу у вигляді твердого осаду.

Очищені води будуть виділятимуться із флокуляційної камери до трубчастого відстійника, де тверді частинки осідатимуть. Потім воду фільтрують

Dnipropetr. Univ. Bull. Ser.: Geol., geogr. 2015. 23(1) 
під тиском для видалення твердого осаду, який i $\epsilon$ первинна сировина для отримання корисних хімічних сполук [4].

Висновки. Таким чином, побічний ефект промислового виробництва термічно й хімічно забруднені підземні води - можна ефективно застосовувати в енергетиці і для очищення геологічного середовища за мінімальних додаткових звитрат на концентрацію, транспортування та отримання корисного продукту за рахунок застосування відомих технічних пристроїв - теплової помпи або породного акумулятора.

\section{Бібліографічні посилання}

1. Belyaev, N. M. The Thermodynamics [Text]/ N. M. Belyaev. - K.: Higher school, 1987. $-344 \mathrm{p}$.

2. Belyaev, N. M. The bases of heat transfer [Text]/ N. M. Belyaev. - K.: Higher school, 1989. $-343 \mathrm{p}$.

3. Dikiy, N. A. The energy devises of geothermal power plants [Text]/ N. A. Dikiy. - K.: Higher school, 1989. - 198 p.

4. Glushkov, A. I. The environment protection under underground coal gasification [Text]/ A. I. Glushkov, B. I. Kondyrev. - Novosibirsk, 1994. - 129 p.

5. Hydrodynamics and heat exchange of mono- and biphasic streams [Text]/ ed. L. N. Schukina // Trudy of Moscow energy institute № 131. - M., 1986. - 162 p.

6. Hydrodynamics and heat exchange of mono- and biphasic streams [Text]/ ed. L. N. Schukina // Trudy of Moscow energy institute №132. - M., 1987. - 132 p.

7. Sou, S. The hydrodynamics of multiphase systems [Text]/ S. Sou; english trans. by V. S. Danilin [et al]. - M.: The World, 1971. - 536 p.

8. The Earth heat and its extraction [Text]/ A. N. Scherban [et al]. - K.: Nauk. dumka, 1974. $-262 \mathrm{p}$.

9. The energy production and distribution system of industries: tutorial [Text]/ ed. A. P. Nesenchuka. - Mn.: Higher school, 1989. - 279 p.

10. Zholudev, S. V. The ground of brown coal underground gasification and incineration with use of subsoil waters [Text]: autoref. of Candidate of tech. Sciences /

Zholudev S. V. - 2008. - 19 p.

11. Zysin, I. A. The Hydraulics of vapor-liquid flows. tutorial [Text]/ I. A. Zysin, E. L. Kitanin. - L.: LPI publishing, 1973. - 76 p. 